\title{
Neotypes for some upper Silurian acanthodian taxa from the Baltic Sea Region and the Welsh Borderland
}

\author{
Carole J. Burrow ${ }^{\mathrm{a}}$ and Tiiu Märss ${ }^{\mathrm{b}}$ \\ ${ }^{a}$ Geosciences, Queensland Museum, 122 Gerler Rd, Hendra, Queensland, Australia; carole.burrow@gmail.com \\ ${ }^{\mathrm{b}}$ Department of Geology, School of Science, Tallinn University of Technology, Ehitajate tee 5, 19086 Tallinn, Estonia; \\ tiiu.marss@taltech.ee
}

Received 21 October 2021, accepted 14 December 2021, available online 20 January 2022

\begin{abstract}
The type material of acanthodian taxa from the upper Silurian of Estonia, erected by C. Pander and V. Rohon in the nineteenth century, has long been lost, and in most cases no neotypes have been erected to date. We nominate scales of Nostolepis striata Pander and Gomphonchus sandelensis (Pander) from the type locality at the Ohesaare Cliff, Saaremaa Island, Estonia, as neotypes for those two species. We also nominate a replacement neotype scale for Radioporacanthodes biblicus (Lehman) from the vicinity of the type locality at Ramsåsa, southern Sweden, to replace the invalid neotype from a borehole on Saaremaa Island. The validity and distribution of Gomphonchus volborthi (Rohon) is considered, and a neotype and type stratum (the Ludlow Bone Bed, Shropshire) are designated. Specimen repository details, where not provided in the original descriptions, are listed for other acanthodian scale-based taxa from the Baltic Sea Region.
\end{abstract}

Key words: stem Chondrichthyes, Acanthodii, Baltic Sea Region, Welsh Borderland, upper Silurian.

\section{INTRODUCTION}

Specimens from the bone beds of the Ohesaare Cliff on Saaremaa Island, Estonia (Fig. 1A, B), were the basis for the taxonomic description of vertebrate microremains by Christian Pander in 1856. All of the type specimens for the taxa erected by Pander have been long lost, but neotypes have never been nominated for any of his stem chondrichthyan (acanthodian) species. After Pander's (1856) publication, more species were subsequently erected for acanthodian scales from Saaremaa Island by Rohon (1893) and Hoppe (1931), but Gross (1947) regarded these taxa as junior synonyms of Pander's two species Gomphodus sandelensis and Nostolepis striata. Similarly, Gross also regarded many of the species erected by Brotzen (1934) and Lehman (1937) for acanthodian scales from Baltic-derived Lochkovian erratics in northern Germany and from the upper Silurian of Scania, Sweden, respectively, as junior synonyms of G. sandelensis and N. striata. Gross (1947) did, however, consider three species - Poracanthodes punctatus Brotzen (1934), P. porosus Brotzen (1934) and Diplacanthoides robustus Brotzen (1934) - to be valid taxa, although he reassigned the last species to Nostolepis robusta. Gross (1971) also erected another species Nostolepis gracilis for acanthodian scales found at the Ohesaare Cliff and in Balticderived erratics and emended Gomphodus to Gomphonchus as the former name was occupied by the Cretaceous heterodontiform shark Gomphodus Reuss, 1846. Gross (1947) considered Thelolepis volborthi Rohon, 1893, Diplacanthoides elegans Brotzen, 1934 and Poracanthus biblicus Lehman, 1937 to be junior synonyms of Gomphonchus sandelensis, Nostolepis striata and Poracanthodes porosus, respectively, but Vergoossen (1999a, 2002) considered these to be valid species; Valiukevičius (2004) also regarded Diplacanthoides elegans as a valid species. Since Gross's publications, many new acanthodian species from upper Silurian type localities in the Baltic have been raised (e.g. Märss 1986; Valiukevičius 1998, 2003a, 2004), with that type material all catalogued and reposited in institutional collections.

Acanthodian taxonomy has undergone some dramatic changes since the work of J. Valiukevičius and J. Vergoossen. Current consensus is that all acanthodians are stem chondrichthyans, but many taxa formerly included in the Order Climatiiformes within the group are outside the Acanthodii clade (e.g. Coates et al. 2018). Most of these taxa do not have superposed growth zones 
A

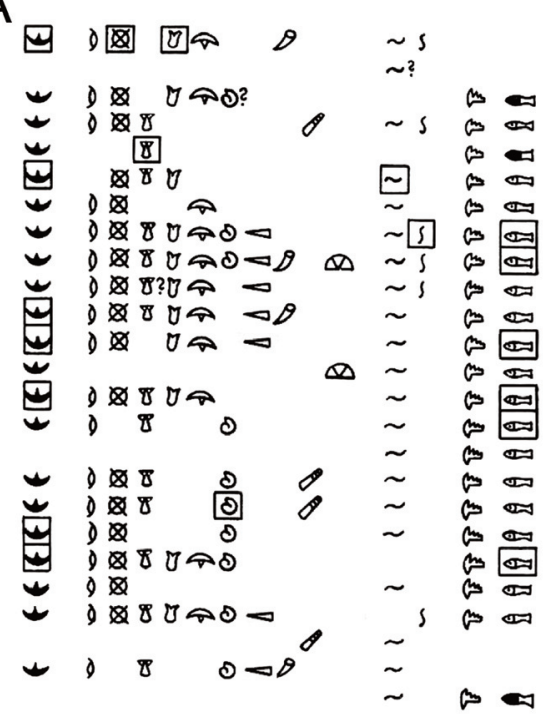

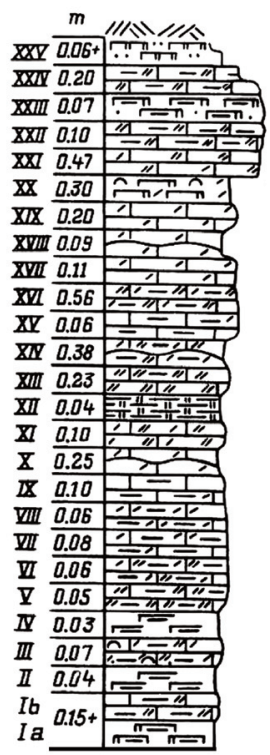

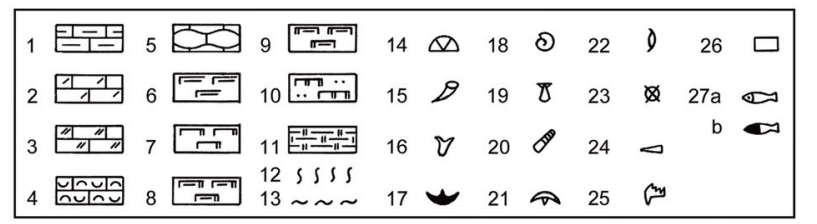

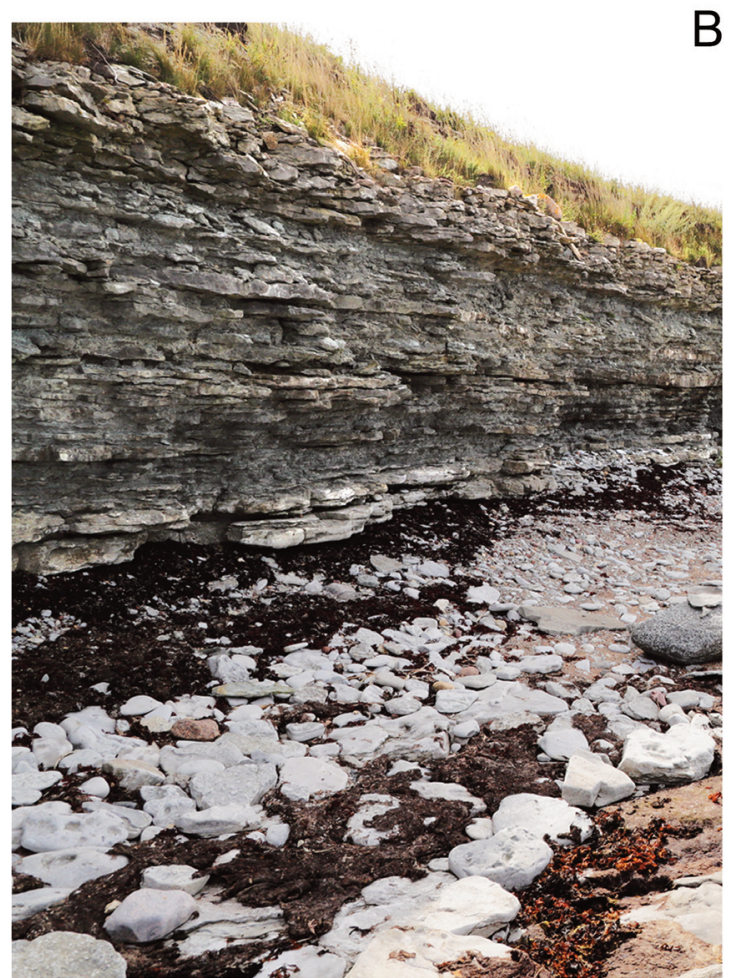

Fig. 1. Ohesaare Cliff, Saaremaa Island, Estonia. A, stratigraphic column (after Mark-Kurik et al. 1989, p. 33, Stop 7 fig., and explanation of figures); B, photograph of the cliff by TM. [Limestones: 1, argillaceous; 2, fine-skeletal; 3, coarse-skeletal; 4, biomorphous; 5, nodular. Mudstones: 6, argillaceous; 7, magnesian calcareous; 8, magnesian argillaceous; 9, calcitic argillaceous; 10, silty calcareous; 11, magnesian clay. Fossils: 12, vertical trace fossils; 13 , horizontal trace fossils; 14 , tabulate corals; 15 , rugose corals; 16, bryozoans; 17, brachiopods; 18, gastropods; 19, bivalves; 20, nautiloids; 21, trilobites; 22, ostracodes; 23, echinoderms; 24 , tentaculites; 25 , conodonts; 26 , fossils occurring in abundance; 27 , fish remains: a - scales and fragments; $b$-articulated shields.]

on scale crowns and also lack perichondral ossification of the scapulocoracoid. Of the genera under consideration here, Nostolepis and Nostovicina are now considered to be Subclass Acanthodii, order and family indeterminate; Gomphonchus is Subclass Acanthodii, Order Ischnacanthiformes, Family Ischnacanthidae; Radioporacanthodes, Poracanthodes and Gomphonchoporus are Subclass Acanthodii, Order Ischnacanthiformes, Family Poracanthodidae; Jolepis is Chondrichthyes, order indeterminate (Burrow, 2021). Here we nominate neotypes for Gomphonchus sandelensis, Nostolepis striata and Radioporacanthodes biblicus, discuss the validity of Gomphonchus volborthi and list the repository details which have not previously been published for other Baltic stem chondrichthyan species considered to be valid, viz. Nostovicina elegans, Gomphonchoporus hoppei, Poracanthodes punctatus, Radioporacanthodes porosus and Jolepis robusta.

The following institutional collection abbreviations are used in this article: GIT, Department of Geology, Tallinn University of Technology, Estonia; MB.f, Museum für Naturkunde, Fish Collection, Berlin, Germany; NHMUK PV, Natural History Museum, Vertebrate Palaeontology Collection, London, England; NRM-PZ, Naturhistoriska Riksmuseet, Palaeozoological Collection, Stockholm, Sweden; RGM, Rijksmuseum van Geologie en Mineralogie, now incorporated in the Nationaal Natuurhistorisch Museum (NNM), Naturalis Biodiversity Center, Leiden, Netherlands; PIN, The Orlov Paleontological Museum, Borissiak Paleontological Institute of the Russian Academy of Sciences, Moscow, Russia.

\section{MATERIAL AND METHODS}

Scale material (GIT 845-1 to GIT 845-33; GIT 845-41; GIT 845-42) from Saaremaa Island, Estonia, used for SEM studies comes from the Sakla core, depth 14.47-14.65 m; Kingissepa core, depth 21.20-21.30 m; Suurlahe-738 core, depth 12.0-12.3 m; Kaugatuma core, depth 56.35-56.55 m [Uduvere Beds of the Paadla Regional Stage (RS)]; Laadjala outcrop (Tahula Beds of the Kuressaare RS) and 
from the Ohesaare Cliff sections I-8 and II-7 (Ohesaare RS). Thin sections have been made from the scales (GIT 845-34 to GIT 845-40) taken from the Sakla core, depth $13.1 \mathrm{~m}$, and Laadjala outcrop (Tahula Beds of the Kuressaare RS) (see Märss 1986, figs 3, 31, 32, 33, 35).

Scales from the Ludlow Bone Bed, Shropshire, England, are from the Tor Ørvig collection, NRM. Netherlands erratic scales are from a sample JV84 in Jo Vergoossen's collection, reposited in the NNM. The PIN scale was photographed using a light microscope and camera. Newly catalogued NRM scales from the Ludlow Bone Bed were imaged uncoated using a Hitachi Tabletop TM-1000 environmental scanning electron microscope (ESEM) at the Queensland Museum, Brisbane, Australia, and thin sections of other NRM Ludlow Bone Bed scales fixed to glass slides with Crystalbond-30 were ground manually using 2000-grit wet and dry sandpaper, then covered with Eukitt mounting medium and a coverslip and imaged using an Olympus BX-50 microscope and DP-12 imaging system. In Estonia, SEM images were made with a Zeiss Ultra 55 (FEG) and Zeiss EVO MA15; scales for thin sectioning were fixed to a glass slide with fir balsam and polished with powder $3 \mu \mathrm{m}$ in diameter.

\section{DESIGNATIONS}

\section{Nostolepis striata Pander, 1856}

Scales of Nostolepis striata have been recorded and described extensively since the early twentieth century; the synonymy by Valiukevičius (1998, pp. 30-31) lists the taxa considered junior synonyms for the species. We exclude Gomphodus volborthi from this list (see below). Here we designate GIT 845-3 (Fig. 2A, B) from Saaremaa, Ohesaare Cliff, profile 2, bed VII, Ohesaare RS (upper Silurian, Přidoli) as a neotype for Nostolepis striata to replace the long lost syntypes, being from the type locality and type stratum as far as can be ascertained. The nominated neotype closely resembles one of the syntype scales (Pander 1856, pl. 6, fig. 7), conforms to the original diagnosis and the more extensive descriptions by Gross

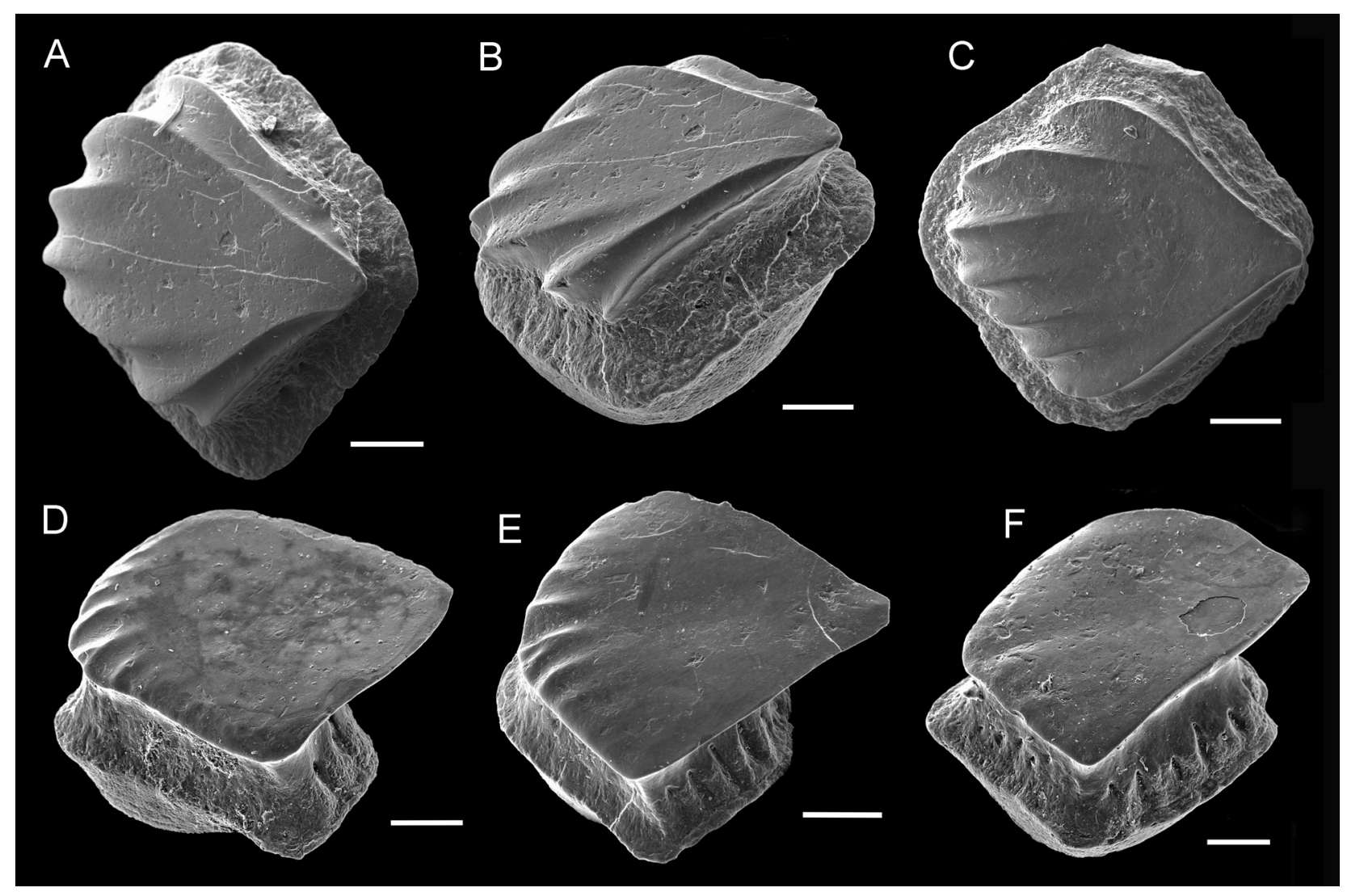

Fig. 2. Scales from profile 2, bed VII, Ohesaare Cliff; Ohesaare Regional Stage. A-C, Nostolepis striata Pander, 1856: A, B, neotype GIT 845-3, in crown and laterocrown views; C, GIT 845-6, asymmetric scale with narrow side crown ledge; D-F, Gomphonchus sandelensis (Pander, 1856): D, neotype GIT 845-14, scale with short weak ridges along anterior crown edge, in laterocrown view; E, GIT 845-11, scale similar to the neotype; F, GIT 845-13, scale with almost smooth crown. Scale bars $=0.1 \mathrm{~mm}$. Anterior is to the left. 
$(1947,1971)$ and thus fits the requirements of ICZN Art. 7.3 (ICZN 1999). We also show another scale from the same stratum (Fig. 2C) to illustrate the N. striata scale form with an asymmetric crown.

\section{Gomphonchus sandelensis (Pander, 1856)}

Scales of Gomphonchus sandelensis have also been recorded and described extensively (see, for example, Denison 1979). Gross (1971) replaced the original genus name Gomphodus with Gomphonchus, as Gomphodus was occupied. The synonymy by Valiukevičius (1998, pp. 30-31) lists the taxa considered junior synonyms for the species, mostly based on the assessments by Gross (1947). Pander's (1856) syntype specimens were from the Ohesaare Cliff and Sandel (bearing the name Sandla today) on Saaremaa Island. Here we designate GIT 84514 (Fig. 2D) from Saaremaa, Ohesaare Cliff, profile 2, bed VII, Ohesaare RS (upper Silurian, Přidoli), as a neotype for Gomphonchus sandelensis to replace the long lost syntypes, being from the nominated type locality and type stratum. The neotype closely resembles the syntype that is most typical for the species (Pander 1856, pl. 6, fig. 16) and conforms to the original diagnosis and the more extensive descriptions of Gross (1947, 1971). We also show other scales from the same stratum (Fig. 2E-F) to illustrate the variation in the development or preservation of the anterior crown ridges in $G$. sandelensis scale forms.

\section{Gomphonchus volborthi (Rohon, 1893)}

Gomphonchus volborthi (Rohon 1893, pl. 1, fig. 14a, b) was originally assigned to the thelodont agnathan genus Thelodus. The specimen described and illustrated by Rohon (1893, fig. 3A) was initially housed in Museum der Kaiserlichen Akademie der Wissenschaften in St Petersburg, but the microremains he described were eventually transferred to their current repository, the Orlov Palaeontological Museum in Moscow and the illustrated specimen was assigned the catalogue number PIN 3257/35 (Fig. 3B). Rohon (1893) listed the following localities for the species occurrence: Ohesaare Cliff; near Oestergarn, Gotland; and the Ludlow Bone Bed in England. Because his monograph was mainly a description of specimens from Oesel (i.e. Saaremaa Island), we could have surmised that the Ohesaare Cliff would be the type locality, but this was not specified. In the introduction, Rohon (1893, p. 5) noted that Dr Volborth provided the specimens from the Ludlow Bone Bed and Gotland, so as the species is named after him, it is probable that the type specimen was from one of these two localities. Rohon (1893, p. 36) wrote that he found twelve specimens in Volborth's material from Oestergarn and another six to eight small, shiny white scales from Oesel and the Ludlow Bone Bed. Unfortunately, the holotype scale was preserved by imbedding in Canada Balsam under a glass cover slip and is now squashed beyond recognition (Fig. 3B). Whereas this scale is acanthodian, the thin section he ascribed to the species (Rohon 1893, text-fig. 7) is a thelodont scale.

Hoppe (1931, table p. 89) considered G. volborthi to be relatively abundant in the Ohesaare Cliff, and it would seem from his description and figured specimens that he assigned the $G$. sandelensis morphotype with radial ridges on the anterior crown to G. volborthi rather than G. sandelensis. Gross $(1947,1971)$ regarded $G$. volborthi as a junior synonym of $G$. sandelensis. Gomphonchus volborthi was considered by Valiukevičius (1998, p. 30; listed as Gomphodus volborthi Lehman, 1937 in the synonymy) to be a junior synonym of Nostolepis striata, but Vergoossen (1999a, p. 43) resurrected it as a valid taxon. However, Vergoossen (1999a) stated that the scales he considered to be $G$. volborthi were only found in strata that are older than those exposed in the Ohesaare Cliff, typically in Thelodus sculptilis zone faunas. Vergoossen (1999a) considered that scales from the Ludlow of Gotland assigned to G. sandelensis by Fredholm (1988, fig. 9C, D) are from G. volborthi not G. sandelensis, although Valiukevičius (2003b) disagreed with this opinion. The type specimen of Rohon (1893, pl. 1, fig. 14a, b; Fig. 3A) was poorly illustrated, but we can glean some information from its present squashed state (Fig. 3B). Its original width is estimated at about $0.5 \mathrm{~mm}$, and it was possibly a creamy brown colour (assuming the Canada Balsam did not affect the coloration). However, scales from all three localities listed by Rohon (1893) can be the same brown colour and size, although most scales are smaller and those from the Ohesaare Cliff bone beds are predominantly black. Scales from the Ludlow Bone Bed (dated as early Přidoli, see Catlos et al. 2020; Fig. 3C-F), Gotland (Fig. 3G) and Groningen erratics (Fig. 3H) that Vergoossen (1999a, 2000) regarded as G. volborthi are older than the scales from the Ohesaare Cliff. We also recognize scales of $G$. volborthi from the Ludlow (Ludfordian) Uduvere Beds of the Paadla RS (Fig. 3I, J) and Tahula Beds of the Kuressaare RS (Fig. 3K), Saaremaa. Vergoossen (2003, pl. 13, figs 111, 112) illustrated the histological structure of scales he classified as G. volborthi from the ' $9 \mathrm{~g}$ ' beds, Ringerike, Norway, which support his observation that the scales have a Gomphonchus-type histology. However, as the morphology for these scales has not been figured, and ' $9 \mathrm{~g}$ ' belongs to a much older Wenlock stratum (Bremer et al. 2019a), we leave those scales out of our discussion. Thin sections of $G$. volborthi scales from the Ludlow Bone Bed, erratic JV84 from the Netherlands and Tahula Beds in Saaremaa (Fig. 3L-P) show the same type of histology. In erecting 


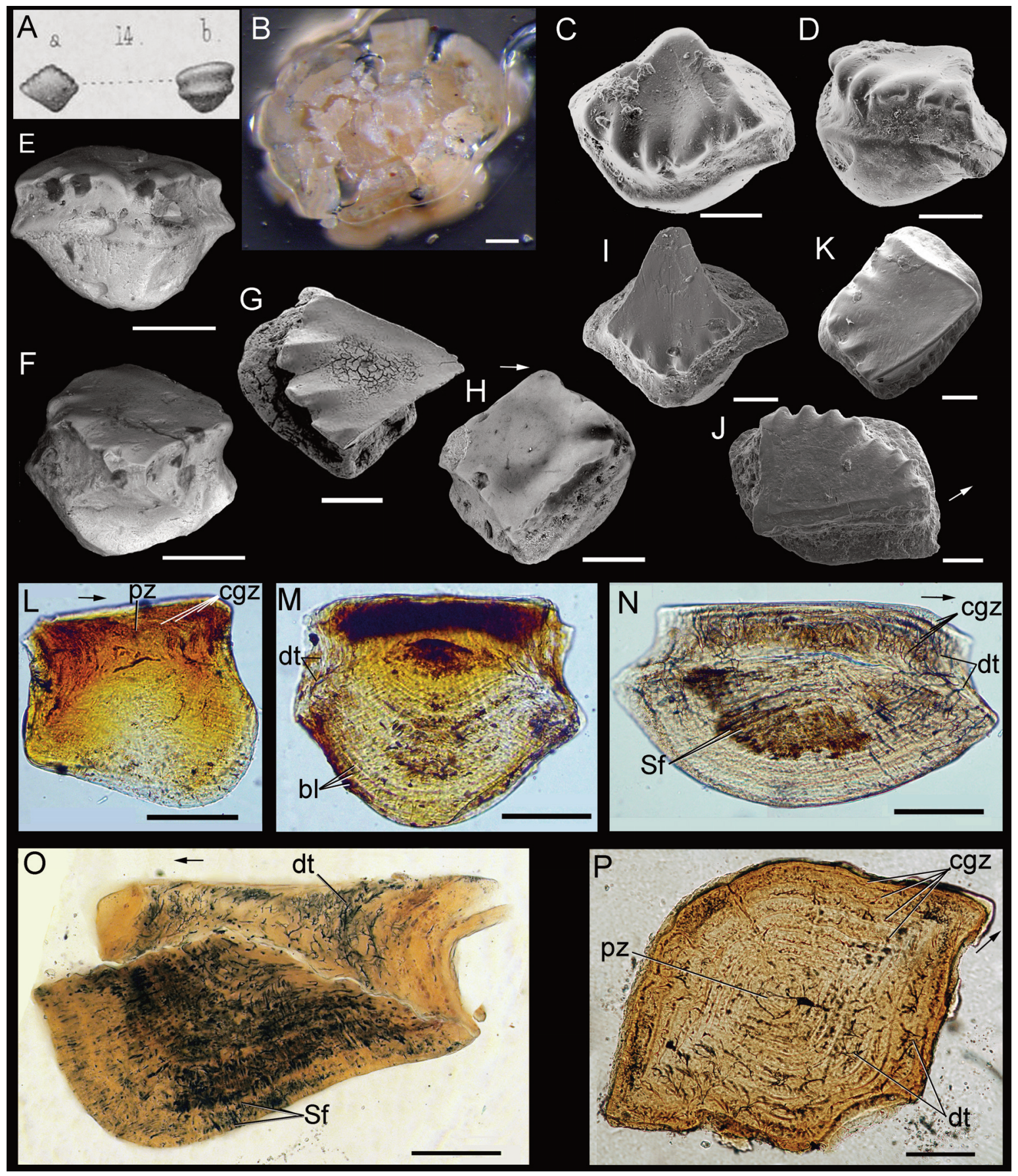

Fig. 3. Gomphonchus volborthi (Rohon, 1893). A, type scale as illustrated by Rohon (1893, pl. 1 fig. 14); B, lectotype PIN $3257 / 35$, imbedded in Canada Balsam, covered with a glass slide, scale now squashed; C-F, scales from the Ludlow Bone Bed (early Přidoli), Ludlow, Shropshire, England: C-D, neotype scale NHMUK PV F63947 crown and anterolateral views (Vergoossen 1999a, fig. 11); E, scale NRM-PZ P 17054, anterior view; F, scale NRM-PZ P 17055, laterocrown view; G, scale NRM-PZ P16360 from G00-26LJ, upper Hamra Formation, Ängvards, Gotland (Bremer et al. 2019b, fig. 10M); H, RGM.1333566 from JV84 erratic, Netherlands; I, scale GIT 845-31 from the Suurlahe-738 core, depth 12.0-12.13 m; J, scale GIT 845-29 from the Kingissepa core, depth 21.2021.30 m; Uduvere Beds, Paadla RS (Ludfordian, Ludlow); K, scale GIT 845-41 from the Tahula Beds, Kuressaare RS; L, M, sections of scales from the Ludlow Bone Bed, probably at Ludlow, Shropshire, England: L, vertical longitudinal section NRM-PZ SI 3501; M, vertical transverse section NRM-PZ SI 3502; N, vertical longitudinal section of scale RGM.1333567 from erratic JV84, Netherlands; $\mathbf{O}, \mathbf{P}$, sections of scales from the Laadjala Bridge outcrop, Saaremaa; Tahula Beds of the Kuressaare RS (Ludfordian, Ludlow): $\mathrm{O}$, vertical longitudinal section GIT 845-37; P, crown horizontal sections GIT 845-39. Scale bars $=0.1 \mathrm{~mm}$ except $\mathrm{N}$ and $\mathrm{O}=0.2 \mathrm{~mm}$. Abbreviations: bl, base lamellae; cgz, crown growth zones; dt, dentine tubules; pz, primordial growth zone; Sf, Sharpey's fibres. 
the species Nostolepis paravolborthi, Valiukevičius (2003b, p. 231) commented that the species was 'related to Gomphonchus volborthi'; N. paravolborthi was subsequently reassigned to Nostovicina paravolborthi by Valiukevičius \& Burrow (2005) based on the histological structure. However, the histological structure of $G$. volborthi scales differs from that of $N$. paravolborthi in having longer unbranched dentine tubules in the crown, dentine tubules extending down into the base and very few bone cell lacunae in the base.

Relying on the information listed here and SEM images of GIT 845-1 up to GIT 845-20, we consider that $G$. volborthi is not present in the Ohesaare Cliff and scales from this locality which Rohon (1893) and Hoppe (1931) assigned to the species are from G. sandelensis. As Rohon (1893) did not specify a type locality and the provenance of the type scale is not known, we nominate the Ludlow Bone Bed as the type stratum and Ludford Lane, Ludlow, Shropshire, England (OS Grid Reference: SO51167413), as the type locality. We designate scale NHMUK PV F63947 from the Ludlow Bone Bed (Vergoossen 1999a, fig. 11; Fig. 3C-D) as the neotype for Gomphonchus volborthi. The geographical and stratigraphic distribution of the species is as follows: upper Silurian, lower Přidoli, Ludlow Bone Bed; Welsh Borderland, U.K. (Vergoossen 1999a); Ludlow to lower Přidoli, ?När to Sundre formations, Gotland, Sweden (Bremer et al. 2019b); Ludlow to lower Přidoli, Öved Sandstone Formation, southern Sweden; upper Ludlow, Uduvere Beds of the Paadla RS and Tahula Beds of the Kuressaare RS, Estonia; uppermost Ludlow/lower Přidoli, Winnica Formation, Holy Cross Mountains, Poland (Bremer et al. 2018); upper Silurian, lower Prridoli, erratics, the Netherlands (Vergoossen 1999c, 2002); possibly Ludlow or Prridoli, reworked deposit in Quaternary gravels, Mazury Quarry, near Minsk, Belarus (Plax 2019).

\section{Radioporacanthodes biblicus (Lehman, 1937)}

Radioporacanthodes biblicus was regarded by Gross (1947) as a junior synonym of Poracanthodes porosus Brotzen, 1934 (now Radioporacanthodes porosus, see Vergoossen 1997), but the species was resurrected by Vergoossen (2002). He noted that the type specimen illustrated by Lehman (1937, pl. 3, fig. 47) is lost and designated a neotype RGM 323051 (Vergoossen 2002, pl. 4, figs 84, 85) from the Tahula 709 drill core, depth $8.4 \mathrm{~m}$, on Saaremaa Island. However, the type specimen was from Ramsåsa, southern Sweden, and according to ICZN Art. 75.3.6 (ICZN 1999), the neotype should be from as close as possible to the original type locality. As some of the 'paratypes' nominated by Vergoossen (2002, p. 53, figs 78-82) are from locality $H$, Ramsåsa, close to the type locality (probably locality F, Ramsåsa, according to
Vergoossen 2002), we designate NRM-PZ 8867 from locality H (Vergoossen 2002, pl. 7, figs 80-82) as the replacement neotype.

\section{Repository details, previously unpublished, for other Baltic taxa}

Here we list catalogue details, not previously published, for type specimens of other Upper Silurian or Lower Devonian taxa deemed valid from the Baltic, including erratics from northern Germany.

Diplacanthoides elegans Brotzen, 1934 was regarded as a junior synonym of Nostolepis striata by Gross (1947), but several authors since (Vergoossen 1999b; Valiukevičius 2004) considered that it should be resurrected as Nostolepis elegans. According to Valiukevičius \& Burrow (2005), the species should, however, be reassigned to Nostovicina Valiukevičius \& Burrow, based on the lack of Stranggewebe in the scale crowns. The Nostovicina elegans lectotype (Brotzen 1934, p. 26, pl. 1, fig. 11a-c) is MB.f. 11937, from erratic limestone boulder Bey. 36 or 37, northern Germany (Lower Devonian, Lochkovian).

Gomphonchoporus hoppei (Gross, 1947) holotype scale MB.f.449 (Gross 1947, pl. 5, fig. 7) from an unknown Beyrichienkalk locality is not lost and illustrates the salient features of the species. Thus, under ICZN Art. 75.3.4 (ICZN 1999), the neotype NNM 423034 nominated by Vergoossen (1999c, p. 243, pl. 4, figs 42-44) from a northern Netherlands erratic is not valid.

Poracanthodes punctatus Brotzen, 1934 syntypes are MB.f.11979a and b (Brotzen 1934, pl. 3, figs 1, 8). Gross (1947, fig. 11A) illustrated the histology of the latter scale and described it as the holotype (Gross 1947, p. 120), so we designate this scale MB.f.11979b as the lectotype. Vergoossen (1999c) nominated an erratic from the northern Netherlands as a new type locality, but this is not correct as the type locality is erratic Bey. 36 from northern Germany; Lower Devonian, Lochkovian.

Radioporacanthodes porosus (Brotzen, 1934) lectotype is MB.f.11989a (Brotzen 1934, pl. 3, fig. 2), also from erratic Bey. 36, northern Germany. Gross (1947, fig. $11 \mathrm{M}$ ) illustrated the pore canal system of a scale (determined by immersing the scale in xylene) captioned as the holotype, so this is presumed to be MB.f.11989a. A short synonymy and revised diagnosis of the taxon were provided by Vergoossen (1999c), in erecting the genus Radioporacanthodes.

Jolepis robusta (Brotzen, 1934) holotype is MB.f.11939 (Brotzen 1934, pl. 2, fig. 6a, b). The species was originally assigned by Brotzen to Diplacanthoides robustus, reassigned to Nostolepis robusta by Gross (1971) and recently to Jolepis robusta by Burrow \& Turner (2018) who gave a synonymy and listed the holotype 
erroneously as MB.f.1191, which is a specimen figured by Gross (1971, pl. 7, fig. 6a, b).

Acknowledgements. CJB thanks the Queensland Museum for provision of facilities, and TM thanks the Department of Geology, Tallinn University of Technology for the opportunity to work with fossil fishes deposited in the geological collections. TM also thanks Mart Viljus and Valdek Mikli for taking SEM images and Gennadi Baranov for improving the pictures of thin sections (all in Tallinn). We are grateful to Jo Vergoossen (Groningen) for providing information, specimens and images of material he studied, Florian Witzmann (MB, Berlin) and Thomas Mörs (NRM, Stockholm) for information on specimens in their collections, Vadim Glinskiy (St Petersburg University, St Petersburg) for tracking down the repository for the Rohon collection microremains and Oleg Lebedev (PIN, Moscow) for photographing the original specimen of Gomphonchus volborthi in its current state. We thank the reviewer Dr H.-P. Schultze and an anonymous referee for their valuable comments. The publication costs of this article were covered by the Estonian Academy of Sciences.

\section{REFERENCES}

Bremer, O., Niedźwiedzki, G., Blom, H., Dec, M. \& Kozłowski, W. 2018. Vertebrate microremains from the upper Silurian Winnica Formation of the Holy Cross Mountains, Poland. Geological Magazine, 155, 1523-1541.

Bremer, O., Turner, S., Märss, T. \& Blom, H. 2019a. Silurian vertebrate remains from the Oslo Region, Norway, and their implications for regional biostratigraphy. Norwegian Journal of Geology, 99, 129-150 + 5 appendices.

Bremer, O., Jarochowska, E. \& Märss, T. 2019b. Vertebrate remains and conodonts in the upper Silurian Hamra and Sundre formations of Gotland, Sweden. GFF, 142, 52-80.

Brotzen, F. 1934. Erster Nachweis von Unterdevon im Ostseegebiete durch Konglomeratgeschiebe mit Fischresten. II Teil (Paläontologie). Zeitschrift Geschiebeforschung, 10, $1-65$.

Burrow, C. J. 2021. Acanthodii, Stem Chondrichthyes. In Handbook of Paleoichthyology, Volume 5 (Schultze, H.-P., ed.). Verlag Dr Friedrich Pfeil, Munich, 135 pp.

Burrow, C. J. \& Turner, S. 2018. Stem chondrichthyan microfossils from the Lower Old Red Sandstone of the Welsh Borderland. Acta Geologica Polonica, 68, 321-334.

Catlos, E. J., Mark, D. F., Suarez, S., Brookfield, M. E., Miller, C. G., Schmitt, A. K., Gallagher, V. \& Kelly, A. 2020. Late Silurian zircon $\mathrm{U}-\mathrm{Pb}$ ages from the Ludlow and Downton bone beds, Welsh Basin, UK. Journal of the Geological Society, 178, jgs2020-107.

Coates, M. I., Finarelli, J. A., Sansom, I. J., Andreev, P. S., Criswell, K. E., Tietjen, K., Rivers, M. L. \& La Riviere, P. J. 2018. An early chondrichthyan and the evolutionary assembly of a shark body plan. Proceedings of the Royal Society B: Biological Sciences, 285, 20172418.

Denison, R. H. 1979. Acanthodii. In Handbook of Paleoichthyology, Volume 5 (Schultze, H.-P., ed.). Gustav Fischer Verlag, Stuttgart and New York, 62 pp.
Fredholm, D. 1988. Vertebrates in the Ludlovian Hemse Beds of Gotland, Sweden. Geologiska Foreningens i Stockholm Forhandlingar, 110, 157-179.

Gross, W. 1947. Die Agnathen und Acanthodier des obersilurischen Beyrichienkalks. Palaeontographica Abt. A, 96, 91-161.

Gross, W. 1971. Downtonische und Dittonische AcanthodierReste des Ostseegebietes. Palaeontographica Abt. A, 136, $1-82$.

Hoppe, K. H. 1931. Die Coelepiden und Acanthodier des Obersilurs der Insel Oesel. Ihre Paläobiologie und Paläontologie. Palaeontographica Abt. A, 76, 38-94.

ICZN. 1999. International Code of Zoological Nomenclature. Fourth Edition. The International Trust for Zoological Nomenclature, London, UK, 306 pp.

Lehman, J.-P. 1937. Les poissons du Downtonien de la Scanie (Suède). Mémoires du Faculté Sciences, Université de Paris, 664, 1-98.

Mark-Kurik, E., Märss, T. \& Kuršs, V. 1989. Excursion Guidebook. The Silurian of Saaremaa and the Devonian of South Estonia and North Latvia. 2nd International Colloquium on the Middle Palaeozoic Fishes. Tallinn, September 1989. Estonian Academy of Sciences Editorial and Publishing Council, Tallinn, 43 pp.

Märss, T. 1986. Silurian vertebrates of Estonia and West Latvia. Fossilia Baltica, 1, 1-104 [in Russian, with English summary].

Pander, C. H. 1856. Monographie der fossilen Fische des silurischen Systems der Russisch-Baltischen Gouvernements. Obersilurische Fische. Buchdruckerei der Kaiserlichen Akademie der Wissenschaften, St. Petersburg, 91 pp.

Plax, D. P. 2019. On the redeposited Silurian ichthyofauna remains in the Quaternary deposits of Belarus. Natural Resources, 2/2019, 34-45.

Reuss, A. E. 1846. Die Versteinerungen der böhmischen Kreideformation. Zweite Abtheilung. E. Schweizerbart'sche Verlagsbuchhandlung, Stuttgart, iv +148 pp.

Rohon, J. von. 1893. Die obersilurischen Fische von Oesel. Teil II. Selachii, Dipnoi, Ganoidei, Pteraspidae und Cephalaspidae. Memoires de l'Académie Impériale des Sciences de St. Petersbourg, VIIe série, 41, 1-124.

Valiukevičius, J. J. 1998. Acanthodians and zonal stratigraphy of Lower and Middle Devonian in East Baltic and Byelorussia. Palaeontographica A, 248, 1-53.

Valiukevičius, J. J. 2003a. New Silurian nostolepids (Acanthodii, Pisces) of Lithuania. Geologija (Vilnius), 42, 51-68.

Valiukevičius, J. J. 2003b. New Late Silurian to Middle Devonian acanthodians of the Timan-Pechora region. Acta Geologica Polonica, 53, 209-245.

Valiukevičius, J. 2004. Silurian succession of the Luzni-4 borehole (Latvia). Acta Universitatis Latviensis, 679, 120147.

Valiukevičius, J. \& Burrow, C. J. 2005. Diversity of tissues in acanthodians with "Nostolepis"-type histological structure. Acta Palaeontologica Polonica, 50, 635-649.

Vergoossen, J. M. J. 1997. Revision of poracanthodid acanthodians. Ichthyolith Issues Special Publication, 3, 4446.

Vergoossen, J. M. J. 1999a. Siluro-Devonian microfossils of Acanthodii and Chondrichthyes (Pisces) from the Welsh Borderland/south Wales. Modern Geology, 24, 23-90. 
Vergoossen, J. M. J. 1999b. Late Silurian fish microfossils from Helvetesgraven, Skane (southern Sweden) (I). Geologie en Mijnbouw, 78, 267-280.

Vergoossen, J. M. J. 1999c. Late Silurian fish microfossils from an East Baltic-derived erratic from Oosterhaule, with a description of new acanthodian taxa. Geologie en Mijnbouw, 78, 231-251.

Vergoossen, J. M. J. 2000. Acanthodian and chondrichthyan microremains in the Siluro-Devonian of the Welsh Borderland, Great Britain, and their biostratigraphical potential. Courier Forschungsinstitut Senckenberg, 223, 175-199.

Vergoossen, J. M. J. 2002. Late Silurian fish microfossils from Ramsåsa, Locality H, Scania, south Sweden, with some remarks on the body zonation scheme used in thelodont studies. Scripta Geologica, 123, 41-69.

Vergoossen, J. M. J. 2003. First record of fish microfossils from Ramsåsa, site C, Skåne, southern Sweden. Scripta Geologica, 126, 1-78.

\section{Mõnede Läänemere regiooni ja Walesi Ülem-Siluri akantoodide taksonite neotüübid}

\section{Carole J. Burrow ja Tiiu Märss}

19. sajandil C. Panderi ja V. Rohoni poolt püstitatud Eesti Ülem-Siluri akantoodide (Acanthodii) taksonite tüüpmaterjal (holotüüp) on kadunud ja enamikul juhtudel ei ole tänaseni määratud neile ka neotüüpe. Esitame kahe liigi Nostolepis striata (Pander) ja Gomphonchus sandelensis (Pander) neotüüpideks soomused Ohesaare panga leiukohast Eestis Saaremaal. Samuti nimetame Radioporacanthodes biblicus (Lehman) kehtetu tüübi asemele neotüübi Lõuna-Rootsist Ramsåsa läheduses paiknevast paljandist ja arutleme liigi Gomphonchus volborthi (Rohon) valiidsuse üle. Näitame ära käsitletud akantoodide tüüpeksemplaride asukohad muuseumide kogudes. 